\title{
Renal Function Studies and Kidney Pyruvate Carboxylase in Subacute Necrotizing Encephalomyelopathy (Leigh's Syndrome)
}

\author{
Alan B. Gruskin, ${ }^{[00}$ Mulchand S. Patel, Michael Linshaw, Robert Ettenger, \\ Dale Huff, and Warren Grover
}

St. Christopher's Hospital for Children and Departments of Pediatrics, Neurology, Biochemistry, and Pathology, Temple University School of Medicine, Philadelphia, Pennsylvania, USA

\section{Extract}

Proximal renal tubular acidosis has been observed in two infants who had lactic acidosis associated with subacute necrotizing encephalomyelitis. Reduced renal thresholds for bicarbonate (18-19.2 mm/liter) were found in both, in conjunction with the ability to excrete normal quantities of acid. In order to raise the level of serum bicarbonate, increasing rates of infusion of solutions containing bicarbonate were required, because of a progressive increase in serum lactate from 18 to $54 \mathrm{mg} / \mathrm{dl}$. The infusion of sodium bicarbonate expanded the extracellular space, as measured by an increase in chloride space of $12.9 \%$. Volume expansion was associated with a progressive fall in bicarbonate reabsorption from a maximum of 1.91 to $1.02 \mathrm{~mm} / 100$ $\mathrm{ml}$ glomerular filtration rate. In addition, the tubular reabsorption of phosphate fell from 80 to $60 \%$, urate clearance increased from 8.7 to $20 \mathrm{ml} / \mathrm{min} / 1.73 \mathrm{~m}^{2}$, lactate clearance increased from 0.23 to $22.9 \mathrm{ml} / \mathrm{min} / 1.73 \mathrm{~m}^{2}$, and chloride excretion increased from 0.7 to $3.14 \mu \mathrm{Eq} / \mathrm{min} / 1.73 \mathrm{~m}^{2}$. At autopsy, reduced activity of renal pyruvate carboxylase was demonstrated for the first time in this disease.

\section{Speculation}

As a reflection of impaired lactate metabolism in subacute necrotizing encephalomyelitis (SNE), generation of ATP may be reduced in the renal cortex. This reduced supply of energy might be expected to impair reabsorption of normal quantities of filtered bicarbonate; proximal renal tubular acidosis may be the result. The fact that other evidence of proximal tubular dysfunction was not observed in the normohydrated state further suggests that failure to reabsorb filtered sodium bicarbonate may be the initial abnormality observed when the supply of energy diminishes in the renal cortex.

The changes in the chloride space observed during bicarbonate infusions may provide data useful in the interpretation of changes in the renal threshold both for bicarbonate and for other solutes.

Finally, it appears that subacute necrotizing encephalomyelitis may include a spectrum of biochemical abnormalities, and that only certain forms may be associated with renal tubular acidosis. 


\section{Introduction}

One hundred cases of SNE have been reported since the original description of the disease by Leigh in 1951 [26]. Affected individuals may appear normal during early infancy. With increasing age, progressive neurologic involvement is manifested by hypotonia, incoordination, oculomotor palsies, visual disturbances, and regressive behavior. The course is progressive, variable in duration, and usually fatal. Pathologic changes include symmetrical necrotizing lesions scattered throughout the basal ganglia, brainstem, cerebellum, and spinal cord [29].

A major feature of SNE is the periodic occurrence of acidosis, which may be associated with increased levels of lactic acid. We will describe a child with SNE in whom there was persistent acidosis with a normal serum lactate level. Following this finding we have demonstrated proximal renal tubular acidosis (RTA) in two subjects with SNE and have examined renal function extensively in one.

This report will present: $(1)$ the clinical course of both patients; (2) the changes of venous lactate in response to the administration of bicarbonate; (3) studies of the renal mechanisms involved in the reabsorption of urate, phosphate, lactate, sodium, and bicarbonate; (4) the changes in transport which occurred as a result of expansion of extracellular volume; and (5) data concerning the renal activity of pyruvate carboxylase.

\section{Case Reports}

SW (SCHC 68-00-538) was a girl born to a 23-year-old mother after an uncomplicated gestation of 39 weeks' duration. Birth weight was 2,670 $\mathrm{g}$ and length was 50 $\mathrm{cm}$. The Apgar score was 9 at 1 min. Over the next 26 $\mathrm{hr}$, the child became jittery, hypothermic $\left(92^{\circ} \mathrm{F}\right)$, and developed pneumonitis. Recovery followed treatment with intravenous fluids, ampicillin, and kanamycin.

The patient did not thrive, and at 6 weeks of age weighed $3,150 \mathrm{~g}$. Studies elsewhere revealed multiple urinary colony counts exceeding $10^{5}$ Escherichia coli, and the patient was treated with sulfisoxazole. Our studies included blood-urea nitrogen $25 \mathrm{mg} / \mathrm{dl}$, serum $\mathrm{Na} 138 \mathrm{mEq} /$ liter, serum K $5.3 \mathrm{mEq} /$ liter, serum Cl $105 \mathrm{mEq} /$ liter, $\mathrm{CO}_{2}$ content $16.1 \mathrm{~mm} /$ liter, $\mathrm{pH} 7.25$, and $\mathbf{P}_{\mathrm{CO}_{2}} 35.5 \mathrm{~mm} \mathrm{Hg}$. Blood lactate levels ranged from 25 to $140 \mathrm{mg} /$ dl (normal $<30 \mathrm{mg} / \mathrm{dl}$ ). Neutropenia was found. The diagnosis of a variant of hyperglycinemia was considered, but it was felt the subject more probably had early SNE because the serum alanine and blood lactate levels were elevated and methylamalonicaciduria was not found. No beneficial effect occurred after therapy with biotin and lipoic acid, $10 \mathrm{mg}$ of each daily. Chemical determinations over the next 17 months revealed a persistent anion gap and hyperlacticacidemia, without hyperchloremia. On several occasions the urinary specific gravity exceeded 1.016 and $2+$ proteinuria was seen. Glycosuria was never found.

When the patient was 7 months old, the presence of proximal RTA was established. Gradually increasing quantities of sodium bicarbonate, ultimately exceeding $120 \mathrm{mEq} / 24 \mathrm{hr}$, were required to maintain the serum $\mathrm{CO}_{2}$ content of the patient above $18 \mathrm{~mm} /$ liter. Neutropenia did not recur. At 19 months of age there was the rapid development of coma and the patient died within a day.

At postmortem examination the patient's weight was $4,050 \mathrm{~g}$. No cardiac defect was found. On light microscopy the kidneys were not remarkable. Examination of the brain revealed bilateral scattered areas of encephalomalacia, with gliosis and neovascularization throughout the white matter of the cerebellum, hippocampal gyrus, dentate nucleus, and white matter of the brainstem.

MG (SCHC 68-00-230) was a boy born after a full term, uncomplicated gestation. Birth weight was 3,930 g. The parents were well, and unrelated. A male sibling had died at the age of 2 years, with SNE confirmed at postmortem examination. On monthly examination our patient's early growth and development appeared to be normal. His blood lactate level, examined initially at the age of 7 months, was found to be $56 \mathrm{mg} / \mathrm{dl}$; the serum alanine was $5 \mathrm{mg} / \mathrm{dl}$. Blood-urea nitrogen was $10 \mathrm{mg} / \mathrm{dl}$, serum $\mathrm{Na} 135 \mathrm{mEq} /$ liter, serum Cl $103 \mathrm{mEq} /$ liter, serum K $4.1 \mathrm{mEq} /$ liter, total $\mathrm{CO}_{2} 17.9 \mathrm{~mm} /$ liter, $\mathrm{pH} 7.26$, and $\mathrm{P}_{\mathrm{CO}_{2}} 38 \mathrm{~mm} \mathrm{Hg}$. Hemogram, urinalysis, blood sugar, electroencephalogram, and roentgenograms of the skeletal system were normal. Over the ensuing 2.5 years it was found that the serum bicarbonate level of the patient would fall below $10 \mathrm{~mm} /$ liter unless he was given bicarbonate in excess of $5 \mathrm{mEq} / \mathrm{kg} / 24 \mathrm{hr}$. On several occasions his serum chloride exceeded $110 \mathrm{mEq} /$ liter without any evidence of an anion gap. On other occasions he had an anion gap exceeding $20 \mathrm{mEq} /$ liter. Over 30 measurements of venous lactate were made. Values ranged from 9 to 62 $\mathrm{mg} / \mathrm{dl}$.

During his 2nd year of life the patient stopped growing and developed progressive neurologic impairment. 
He received thiamine and lipoic acid therapy, the details of which are reported elsewhere [19]. No major therapeutic response occurred.

The patient was first shown to have proximal RTA at the age of 12 months, and a more detailed evaluation of his renal function was made at 32 months. Roentgenograms did not at any time show evidence of rickets. There was gradual clinical deterioration; death came at 38 months of age.

Postmortem examination of the brain revealed numerous punctate areas of red and gray softening scattered throughout the nuclear structures of the central neuronal axis, from the head of the caudate nucleus rostral and/or caudad to the lower cervical spinal cord. The largest lesion almost totally destroyed the putamen and extended into the adjacent globus pallidus, thalamus, and amygdala. The subthalamic nucleus and substantia nigra were extensively involved. The mammillary bodies were spared. Numerous lesions were present in the central nuclear structures of the midbrain, pons, and medulla. The dentate nucleus was totally destroyed. The gray matter was involved, especially in the anterior horns of most of the cervical cord. These lesions had the gross appearance and distribution characteristic of Leigh's SNE. These was moderate fatty metamorphosis of the liver. The kidneys had no significant lesions on gross or microscopic examination.

\section{Methods of Study}

Before any studies were made, informed consent was obtained from the parents.

\section{Hydrogen Ion Excretion}

Timed collections of urine were obtained in both patients during periods of spontaneous acidemia and during administration of oral bicarbonate. Blood was analyzed for $\mathrm{pH}, \mathrm{CO}_{2}$ content, and levels of lactate and creatinine; urine was analyzed for $\mathrm{pH}$, titratable acid, $\mathrm{NH}_{4}$, and creatinine. At the time of determination of the bicarbonate titration curve in the second patient, urine collections were obtained for the determination of net acid excretion when the patient was spontaneously acidotic.

\section{Bicarbonate Titration Curve}

Bicarbonate therapy was stopped $18 \mathrm{hr}$ before the determination of the titration curve. Blood was collected through an indwelling needle from a superficial vein distant from the infusion site. After a priming dose of inulin and 2\% p-aminohippurate (PAH) in $0.9 \% \mathrm{NaCl}$, sufficient quantities of both were administered to maintain the blood level of inulin at $50 \mathrm{mg} / \mathrm{dl}$ and of PAH at $1-3 \mathrm{mg} / \mathrm{dl}$. After the control specimens were obtained, bicarbonate was added to the infusion and no further chloride was given. Three separate infusion rates were utilized: $3.3 \mathrm{ml} / \mathrm{min} / 1.73 \mathrm{~m}^{2}$ until the urinary $\mathrm{pH}$ exceeded 6.1 (the corresponding serum bicarbonate value defines the renal threshold for bicarbonate); $6.2 \mathrm{ml} / \mathrm{min} / 1.73 \mathrm{~m}^{2}$ after the threshold was ascertained; and $13.2 \mathrm{ml} / \mathrm{min} / 1.73 \mathrm{~m}^{2}$ when it became apparent that the rate of rise of serum bicarbonate was inadequate to reach levels at which tubular maximum $\left(T_{m}\right)$ for bicarbonate can be measured. Blood samples were obtained at 20-30-min intervals, and midpoint serum levels were calculated by interpolation for each urine collection period.

\section{Laboratory Methods}

Blood $\mathrm{pH}$ was measured at $38^{\circ}$ with an IL $\mathrm{pH}$ meter [40]. Urine $\mathrm{pH}$ was measured at $25^{\circ}$ with a Corning $\mathrm{pH}$ meter $[41]$ and subsequently corrected for body temperature. Total $\mathrm{CO}_{2}$ contents of serum and urine were determined by the method of Van Slyke and Neill [37]. The $\mathrm{P}_{\mathrm{CO}_{2}}$ and bicarbonate concentrations were calculated from the Henderson-Hasselbach equation [14].

Employing a Fisher titrimeter [42], urinary titratable acid was measured by titration to 7.7 at $25^{\circ}$. Ammonium in urine was determined by retitration to 7.7 after adding formaldehyde, utilizing a modification of the method for determining net acid excretion (Jorgenson [24]). The following methods were also utilized; sodium and potassium, IL flame photometer [40]; chloride, Cotlove et al. [9]; creatinine, Bonsnes and Taussky [4]; phosphorus, Gomori [18]; uric acid, Caraway [7]; lactate, Barker and Summerson [3]; inulin, Walser et al. [38]; and PAH, Smith et al. [31]. Amino acids were determined by column chromatography using a Phoenix amino acid analyzer [43]; osmolality was measured cryoscopically by an Advanced Instruments osmometer [44].

Clearances of inulin, $\mathrm{PAH}$, uric acid, and lactate were calculated by the formula $\mathrm{UV} / \mathrm{P}$ (where $\mathrm{U}$ is urine concentration, in milligrams per $100 \mathrm{ml} ; \mathrm{V}$ is in milliliters per minute; and $\mathrm{P}$ is plasma concentration, in milligrams per $100 \mathrm{ml}$ ), the tubular reabsorption of phosphate (TRP) by the formula

$$
\mathrm{TRP}=100 \times 1 \frac{\mathrm{U}_{\mathrm{PO}_{4}=} \mathrm{P}_{\text {inulin }}}{\mathrm{U}_{\text {inul in }} \times \mathrm{P}_{\mathrm{PO}_{4}=}},
$$


and fractional sodium excretion as

$$
100 \times \frac{\text { filtered } \mathrm{Na}-\text { reabsorbed } \mathrm{Na}}{\text { filtered } \mathrm{Na}} .
$$

Rates of filtration, excretion, and reabsorption of bicarbonate were calculated as described by Edelmann $e t$ al. [14].

Support for the inference that changes in chloride space reflect changes in extracellular fluid (ECF) volume is provided by studies performed in nephrectomized dogs [34] which have shown that changes in sulfate space are similar to those of the chloride space after volume expansion with sodium bicarbonate.

The chloride space was calculated [17] assuming a volume of distribution of chloride of $30 \%$. The quantity of chloride administered (a total of $6 \mathrm{mEq}$ ) and the amount excreted in each urine collection was taken into consideration. Chloride space calculations were made as follows $(1)$ initial ECF volume $=30 \%$ of normal body weight; (2) increase in ECF during the bicarbonate titration curve calculated as follows $(a)$ initial total ECF chloride = initial ECF volume $\times$ initial serum chloride concentration, $(b)$ initial total $\mathrm{ECF}$ chloride + net positive balance of chloride $=$ final total ECF chloride, (c) final total ECF chloride final serum chloride concentration $=$ final ECF volume.

Pyruvate carboxylase (EC. 6.4.1.1) was assayed by a modification [1] of the method of Utter and Keech [36]. Homogenates $(10 \% \mathrm{w} / \mathrm{v})$ of kidney cortex in 0.25 $\mathrm{M}$ sucrose were prepared and lyophilized to release the activity from the mitochondria. The lyophilized samples were taken up to the original volume with distilled water and further diluted, if necessary, to obtain measurable activity. A unit is the amount of enzyme which catalyzes the fixation of $1 \mu \mathrm{mol} \mathrm{H}^{14} \mathrm{CO}_{3}-/ \mathrm{min}$ at $37^{\circ}$.

$$
\text { Results [45] }
$$

\section{Tubular Functions}

An overnight urinary concentrating test showed a specific gravity of 1.021 , with an osmolality of 950 mos$\mathrm{mol} / \mathrm{kg}$ water [13]. Repeated determinations failed to reveal any reducing substances. The uric acid clearance and TRP were normal. Urine cultures were repeatedly negative. Quantitative determination of amino acids in urine gave normal values for the age of the patient.
Table I. Hydrogen ion excretion, lactate levels, and creatinine clearance during periods of spontaneous acidosis and oral

\begin{tabular}{|c|c|c|c|c|c|c|}
\hline \multirow[b]{2}{*}{ Date } & \multicolumn{2}{|c|}{ Venous blood } & \multirow{2}{*}{$\begin{array}{l}\text { Creatinine } \\
\text { clearance, } \\
\mathrm{ml} / \mathrm{min} / \\
1.73 \mathrm{~m}^{2}\end{array}$} & \multicolumn{3}{|c|}{ Urine } \\
\hline & $\begin{array}{l}\mathrm{CO}_{2}, \\
\text { mit' } \\
\text { liter }\end{array}$ & $\begin{array}{c}\text { Lactate, } \\
\mathrm{mg} / \\
100 \mathrm{ml}\end{array}$ & & $\mathrm{pH}$ & $\begin{array}{c}\mathrm{TA}, \mu \mathrm{Eq} / \\
\min / \\
1.73 \mathrm{~m}^{2}\end{array}$ & 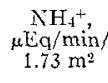 \\
\hline \multicolumn{7}{|l|}{ Patient $M G$} \\
\hline $2 / 4 / 70$ & 18.1 & 49.9 & & 5.46 & 36 & 19 \\
\hline $2 / 10 / 70$ & 21.7 & 41.6 & 43 & 7.15 & 2.6 & 7.4 \\
\hline \multirow[t]{2}{*}{$3 / 27 / 70$} & 14.5 & 37.4 & & 4.98 & 73 & 65 \\
\hline & & & & 5.17 & 54 & 37 \\
\hline $4 / 8 / 70$ & 17.9 & 32 & 47 & 6.35 & 27.3 & 12.3 \\
\hline \multicolumn{7}{|l|}{ Patient SW } \\
\hline $1 / 15 / 69$ & 19.2 & 81.4 & 21 & 6.13 & 1.2 & 19 \\
\hline $1 / 16 / 69$ & 13.3 & 95 & 21 & 4.8 & 21 & 54 \\
\hline $1 / 17 / 69$ & 19.1 & 45.6 & 16 & 6.96 & 1.3 & 8.3 \\
\hline
\end{tabular}
bicarbonate administration ${ }^{1}$

1 TA : titratable acid.

\section{Glomerular Function}

Although the creatinine clearances were somewhat low when $M G$ was 11-13 months of age, the inulin and PAH clearances at 32 months of age were within normal limits. Two Addis counts were normal. Twelve-hour protein excretion totaled $23 \mathrm{mg}$.

\section{Acid Excretion}

Table I shows that the rates of excretion of titratable acid and $\mathrm{NH}_{4}$ in the two children were within ranges previously found in acidotic children. When both patients were spontaneously acidotic, the urine $\mathrm{pH}$ fell below 5.0. Such values indicate the ability to form normal hydrogen ion gradients in the distal tubule. Accordingly, no ammonium chloride loading tests were performed.

\section{Bicarbonate Titration}

Oral bicarbonate was administered to both subjects, and the $\mathrm{pH}$ of the urine was higher than would normally be expected at the observed levels of venous $\mathrm{CO}_{2}$. The bicarbonate threshold in $S W$ was 18-19 $\mathrm{mm} /$ liter, and in $M G$ 18.6-19.2 $\mathrm{mm} /$ liter. Table II contains the results of the bicarbonate titration. The bicarbonate threshold was found at a serum value of $18.6 \mathrm{~mm} /$ liter, whereas the normal threshold is 22 $\mathrm{mm} /$ liter or higher in normal infants [14]. As the serum $\mathrm{CO}_{2}$ rose from threshold values, reabsorption of bicarbonate, calculated in millimolar concentration per liter per $100 \mathrm{~m} 1$ per glomerular filtration rate, progressively fell; $\mathrm{T}_{\mathrm{m}}$ values could not be obtained. The simultaneously determined increase in the chloride space 
Table II. Results of bicarbonate infusion and simultaneous chloride space determinations ${ }^{1}$

\begin{tabular}{|c|c|c|c|c|c|c|c|c|c|c|c|}
\hline \multirow{2}{*}{ Time, $\min$} & \multicolumn{2}{|c|}{ Urine } & \multicolumn{2}{|c|}{ Urine, $\underset{\mathrm{m}^{2}}{\mu \mathrm{Eq}} / \min / 1.73$} & \multicolumn{3}{|c|}{ Bicarbonate, $\mathrm{mmol} / 100 \mathrm{ml} \mathrm{GFR}$} & \multirow{2}{*}{$\begin{array}{l}\text { Serum } \\
\text { chloride, } \\
\mathrm{mEq} / \mathrm{liter}\end{array}$} & \multirow{2}{*}{$\begin{array}{c}\text { Chloride } \\
\text { excretion } \\
\text { (cumulative } \\
\text { urine), } \\
\text { mEq }\end{array}$} & \multirow{2}{*}{$\begin{array}{l}\text { Total } \\
\text { chloride in } \\
\text { chloride } \\
\text { space, } \\
\text { mEq }\end{array}$} & \multirow{2}{*}{$\begin{array}{l}\text { Chloride } \\
\text { space, } \\
\text { liters }\end{array}$} \\
\hline & $\mathrm{V}, \mathrm{ml}_{1.73 \mathrm{~m}^{2}}$ & $\mathrm{pH}$ & $\mathrm{TA}$ & $\mathrm{NH}_{4}^{+}$ & Filtered & Excreted & $\begin{array}{l}\text { Reab- } \\
\text { sorbed }\end{array}$ & & & & \\
\hline \multicolumn{12}{|c|}{$\begin{array}{l}\text { Loading and sus- } \\
\text { taining dose } \\
\text { of inulin and } \\
\text { PAH }\end{array}$} \\
\hline $2-91$ & 0.68 & 4.62 & 35 & 28 & 1.19 & 0 & 1.19 & 117 & 1.79 & 327.6 & 2.78 \\
\hline \multicolumn{12}{|l|}{ Infusion 1} \\
\hline $92-148$ & 0.7 & 4.69 & 32 & 29 & 1.30 & 0 & 1.30 & 118 & 2.40 & 325.8 & 2.75 \\
\hline $149-183$ & 0.824 & 4.72 & 37 & 33 & 1.38 & 0 & 1.38 & 120 & 3.09 & 324.7 & 2.7 \\
\hline $184-199$ & 0.774 & 4.77 & 38 & 33 & 1.50 & 0 & 1.50 & 120 & 3.41 & 324.1 & 2.7 \\
\hline \multicolumn{12}{|l|}{ Infusion 2} \\
\hline $200-233$ & 0.970 & 4.86 & 37 & 25 & 1.68 & 0 & 1.68 & 115 & 4.27 & 323.8 & 2.81 \\
\hline $234-266$ & 1.112 & 6.47 & 14 & 10 & 1.86 & 0.466 & 1.855 & 109 & 5.21 & 322.8 & 2.96 \\
\hline $267-295$ & 1.561 & 8.11 & & & 2.0 & 0.940 & 1.906 & 113 & 6.10 & 322.4 & 2.85 \\
\hline $296-323$ & 1.590 & 8.21 & & & 1.92 & 0.1254 & 1.794 & 113 & 6.71 & 321.1 & 2.84 \\
\hline \multicolumn{12}{|l|}{ Infusion 3} \\
\hline 324-369 & 1.829 & 8.22 & & & 1.86 & 0.176 & 1.684 & 112 & 7.30 & 320.8 & 2.84 \\
\hline $370-397$ & 2.751 & 8.12 & & & 2.07 & 0.3850 & 1.685 & 111 & 7.69 & 320.3 & 2.88 \\
\hline $398-420$ & 4.654 & 8.17 & & & 2.22 & 0.570 & 1.650 & 109 & 8.26 & 319.3 & 2.93 \\
\hline $421-432$ & 7.55 & 8.04 & & & 2.33 & 0.920 & 1.411 & 106 & 8.81 & 318.8 & 3.01 \\
\hline \multicolumn{12}{|l|}{ Infusion 4} \\
\hline $433-450$ & 6.314 & 8.06 & & & 2.48 & 1.238 & 1.242 & 104 & 10.28 & 317.3 & 3.05 \\
\hline $451-485$ & 12.069 & 7.96 & & & 2.97 & 1.558 & 1.412 & 99 & 14.59 & 313.0 & 3.16 \\
\hline $486-510$ & 15.820 & 7.91 & & & 3.10 & 1.761 & 1.339 & 103 & 18.24 & 309.2 & 3.00 \\
\hline $511-530$ & 21.00 & 7.97 & & & 3.12 & 2.094 & 1.020 & 100 & 21.91 & 305.3 & 3.05 \\
\hline
\end{tabular}

i The patient's length was 30 inches, weight $9.32 \mathrm{~kg}$, and surface area $0.42 \mathrm{~m}^{2}$. The original chloride space was taken as $30 \%$ of body weight, i.e., $0.3 \times 9.32 \mathrm{~kg}=2.796$ liters; initial total chloride $=117 \mathrm{mEq} \mathrm{Cl}-\times 2.796=327.6 \mathrm{mEq}$. The rate and bicarbonate composition of the solution infused were Infusion $1,3.3 \mathrm{ml} / \mathrm{min} / 1.73 \mathrm{~m}^{2}$ and $0 \mathrm{~mm} /$ liter; Infusion $2,3.3 \mathrm{ml} / \mathrm{min} / 1.73 \mathrm{~m}{ }^{2}$ and $300 \mathrm{~mm} / \mathrm{liter}$; Infusion 3, $6.2 \mathrm{ml} / \mathrm{min} / 1.73 \mathrm{~m}^{2}$ and $300 \mathrm{~mm} /$ liter; and Infusion $4,13.2 \mathrm{ml} / \mathrm{min} / 1.73 \mathrm{~m}^{2}$ and $300 \mathrm{~mm} /$ liter. TA: titratable acid; GFR: glomerular filtration rate.

Table III. Changes in renal function with volume expansion ${ }^{1}$

\begin{tabular}{|c|c|c|c|c|c|c|c|c|}
\hline \multirow{2}{*}{$\begin{array}{l}\text { Infusion rate, } \\
\mathrm{ml} / \mathrm{min} / 1.73 \mathrm{~m}^{2}\end{array}$} & \multirow{2}{*}{$\begin{array}{c}\text { Chloride space, } \\
\text { liters }\end{array}$} & \multicolumn{4}{|c|}{ Clearances, $\mathrm{ml} / \mathrm{min} / 1.73 \mathrm{~m}^{2}$} & \multirow{2}{*}{ TRP, \% } & \multicolumn{2}{|c|}{ Excretion rates } \\
\hline & & Inulin & PAH & Urate & Lactate & & $\begin{array}{l}\text { Chloride, } \mathrm{mEq} / \\
\mathrm{min} / 1.73 \mathrm{~m}^{2}\end{array}$ & $\begin{array}{l}\text { Lactate, } \mathrm{mg} / \\
\mathrm{min} / 1.73 \mathrm{~m}^{2}\end{array}$ \\
\hline 3.3 & 2.81 & 113.1 & 604 & 8.73 & 0.23 & 80.2 & 0.7 & 0.067 \\
\hline 6.2 & 2.94 & 117.6 & 639 & 14.21 & 12.5 & 40.4 & 0.5 & 5.04 \\
\hline 13.1 & 3.07 & 108 & 600 & 20.1 & 22.9 & 61.0 & 3.14 & II.1I \\
\hline
\end{tabular}

1 Table III contains the average values of three sequential collection periods at each constant infusion rate. PAH : $p$-aminohippuric acid; TRP: tubular reabsorption of phosphate.

provides evidence that expansion of extracellular volume occurred.

The data for TRP, chloride excretion, lactate excretion, and urate clearance were grouped according to infusion rates and the average values of the last three collection periods at each infusion rate are shown in
Table III. Although increasing rates of infusion, i.e., volume expansion, did not change glomerular filtration rate or PAH clearance, the lactate excretion and clearance and the urate clearance increased and the TRP decreased. The changes in urate and phosphate occurred before any change in chloride excretion. 
The fractional excretion of filtered sodium increased as volume expansion occurred. The progressive decrease in sodium reabsorption was associated with a progressive drop in bicarbonate reabsorption (Fig. 1). At the beginning of the bicarbonate titration, venous lactate was within the normal range. Serum lactate values progressively rose as serum bicarbonate increased (Fig. 2).

As shown in Table IV, the kidney of the patient had a negligible amount of pyruvate carboxylase (Experiment $I$ ) compared with controlled values (1-3.5 units activity) (Experiments $I I-I V)$. Although some pyruvate carboxylase activity was lost during storage, the control tissues retained a large amount of enzyme activity (Experiments $I I$ and IV). In rat kidney cortex, the levels of pyruvate carboxylase were very high and are

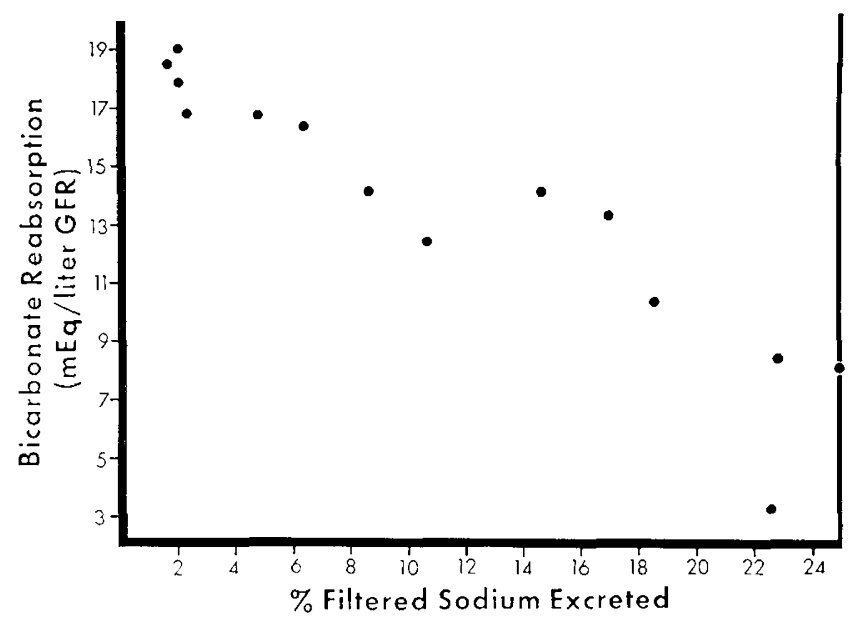

Fig. 1. The relation between progressive depression in bicarbonate reabsorption and increasing fractional sodium excretion is seen.

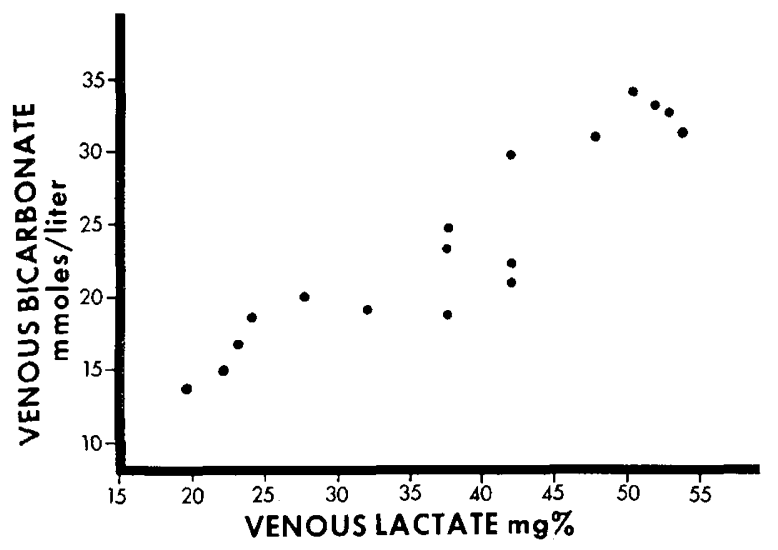

Fig. 2. A progressive increase in venous lactate and serum bicarbonate was observed.
Table $I V$. Activity of pyruvate carboxylase in kidney of patient and control subjects ${ }^{1}$

\begin{tabular}{cc}
\hline Source & $\begin{array}{c}\text { Kidney pyruvate } \\
\text { carboxylase, } \\
\text { units/g tissue }\end{array}$ \\
\hline
\end{tabular}

Experiment $I$ (patient)

a. Autopsy performed $6 \mathrm{hr}$ after death

0.034 (tissue frozen for 5 days)

Experiment II (human control, $9 \mathrm{mo}$, drowning)

a. Autopsy performed $5 \mathrm{hr}$ after death (fresh tissue)

$b$. Tissue frozen for 16 days

c. $I I b+I a$ frozen for 25 days

d. Tissue frozen for 3 months

0.369

0.364

0.163

Experiment III (human control)

a. Autopsy performed $24 \mathrm{hr}$ after death $\quad 1.083$ (fresh tissue)

b. IIIa + Ia frozen for 25 days

Experiment IV (human control, $5 \mathrm{mo}$, multiple congenital anomalies)

a. Autopsy performed $15 \mathrm{hr}$ after death, $\quad 3.40$ fresh tissue

$b$. Tissue frozen for 7 days

Experiment $V$ (rat, animal controls)

a. Fresh tissue

1 Value is the mean \pm SEM for the number of animals shown in parentheses.

in keeping with previous observations [2]. No inhibitory effect on pyruvate carboxylase activity in control tissue was observed when mixed with the kidney tissue of the patient (Experiments IIC and IIIb).

\section{Discussion}

Four distinct aspects of our patient's problem require elaboration: the occurrence of proximal RTA; the interrelationships in transport of multiple solutes in the kidney when bicarbonate is infused or when extracellular volume expansion occurs; the effect of alkalinization on blood lactate levels; and the implications of low renal pyruvate carboxylase activity.

The diagnosis of proximal RTA is established by the demonstration of a "bicarbonate leak" [33] (a lower than normal serum bicarbonate level associated with a urine which contains bicarbonate and has a disproportionately high $\mathrm{pH}$, with the abilities preserved both to reduce urinary $\mathrm{pH}$ to below 5.0 and to excrete adequate quantities of titratable acid and $\mathrm{NH}_{4}$ ). When proximal RTA is associated with multiple dysfunctions of the proximal tubule, defects in tubular transport of uric acid, phosphate, glucose, and amino acids occur. 
Both our subjects demonstrated a proximal defect in acidification when given oral bicarbonate. Before volume expansion, patient $M G$ demonstrated only an isolated defect in "bicarbonate reabsorption." Whether the RTA in these patients represents part of the syndrome complex of lactic acidosis with SNE or an effect of chronic hyperlactatemia on proximal tubule function similar to that observed in heavy metal poisoning cannot be resolved. The lacticacidemia in SNE is extremely variable and at times is in the normal range. The fortuitous finding of normal venous lactate levels at the start of the bicarbonate titration curve suggests that proximal RTA is part of the symptom complex of SNE, and not a secondary effect of the lactate ion. On the other hand, it is possible that persistent hyperlacticacidemia may produce irreversible damage to proximal tubular cells. In this regard, it may be noted that acute infusions of lactic acid do not significantly affect fractional tubular reabsorption of sodium in normal dogs [11].

Of the reported cases of lactic acidosis with SNE one case [39] had a urine $\mathrm{pH}$ of 6 when the plasma bicarbonate was $15 \mathrm{mEq} /$ liter. A reducing substance was also observed: At another time a urine $\mathrm{pH}$ of 5.5 was associated with a $\mathrm{CO}_{2}$ content of $15.5 \mathrm{~mm} /$ liter, generalized aminoaciduria was found. In a sibling with SNE plasma bicarbonate levels varied from 12 to $19 \mathrm{mEq} / \mathrm{li}$ ter, with $\mathrm{pH}$ in urine varying from 5.5 to 6.5 [39]. Generalized aminoaciduria and phosphaturia were demonstrated. In another patient whose serum bicarbonate ranged from 8.6 to $20.3 \mathrm{mEq} /$ liter urine $\mathrm{pH}$ ranged from 4.5 to 7.7 , but precise correlation cannot be made from the available data [15]. Discontinuation of alkalinization therapy led rapidly to $\mathrm{CO}_{2}$ levels of $13 \mathrm{mEq} /$ liter in another child with SNE [23]. Although such a rapid fall occurs in proximal RTA when bicarbonate therapy is discontinued, studies of urine were not obtained and the fall may have resulted from continuous production of lactic acid. In any case, it would appear that sufficient patients have been found with both SNE and evidence of proximal RTA to establish this association as a clinical entity.

Not all forms of hyperlacticacidemia need have persistent RTA. An infant with Down's syndrome and idiopathic lactic acidosis had a urine $\mathrm{pH}$ of 4.5 when her blood pH was 7.31 and her serum $\mathrm{HCO}_{3} 25 \mathrm{mEq} /$ liter, which suggests that renal acidification was normal [21]. Other entities with hyperlactatemia may, on the other hand, be associated with RTA. A patient with type $I$ glycogen storage disease and hyperlactatemia has been reported to have urine $\mathrm{pH}$ values of
5.6-5.9 while his serum $\mathrm{CO}_{2}$ varied from 9.5 to 12.0 $\mathrm{mm} /$ liter, which suggests proximal RTA [25]. Studies of additional subjects with various forms of lactic acidosis are needed to establish the precise relation between hyperlactatemia and RTA.

Our patient's inability to raise his serum bicarbonate level necessitated increases in both the concentration and rate of infusion of bicarbonate. The progressive increase in EGV provides an explanation for the progressive drop in bicarbonate reabsorption as the serum bicarbonate rose [27].

It was impossible to ascertain the $T_{m}$ for bicarbonate reabsorption. Recent studies indicate that if the rate of infusion of bicarbonate is kept minimal, a $T_{m}$ for bicarbonate, as classically defined, may not be demonstrable. Similar findings are available for glucose [31]. Accordingly, a certain degree of volume expansion may be necessary to demonstrate certain $T_{m}$ values, whereas excessive degrees of volume expansion may render impossible the demonstration of tubular maxima for these same substances.

Expansion and contraction of ECV have been demonstrated, respectively, to depress or increase proximal tubular reabsorption of bicarbonate, uric acid, phosphate, glucose, and amino acids in subjects with Fanconi's (cystinosis) [27] or Lowe's syndrome [6]. The renal transport mechanisms of all of these substances may be depressed in normal animals by volume expansion, which may influence both threshold and $T_{m}$.

Additional evidence of the effects of progressive volume expansion in our patient is given by the marked changes in urate clearance, TRP, the clearance of lactate and its excretion, and possibly the rate of excretion of chloride. In data reported previously which deals with bicarbonate titration curves, these variables have not been considered in relation to the renal threshold for bicarbonate, to $T_{m}$ bicarbonate, or to the rate of infusion. Data of this nature may help to define the bicarbonate titration curve. For example: $T_{m}$ $\mathrm{HCO}_{3}$ might occur only if there is depression of reabsorption of other substances; $\mathrm{T}_{\mathrm{m}} \mathrm{HCO}_{3}$ may be demonstrable only if rates of infusion are used which produce certain degrees of volume expansion; and the normal renal threshold for bicarbonate may need to be defined as established only when the excretion of other substances is within certain preset limits. Oetliker [27] found that an infusion rate of $9.7 \mathrm{ml} / \mathrm{min} / 1.73 \mathrm{~m}^{2}$ depressed bicarbonate transport in children with Lowe's syndrome. In our subject, a rate of infusion of $6.2 \mathrm{ml} / \mathrm{min} / 1.73 \mathrm{~m}^{2}$ was sufficient to depress not only 
bicarbonate, but also lactate, urate, and phosphate transport.

The rate of excretion of chloride may also reflect the degree of volume expansion during bicarbonate titration. With progressive volume expansion, a decrease in proximal sodium reabsorption may lead to increased delivery of both sodium and chloride distally [5]. That chloride excretion rises later than lactate, phosphate, or urate excretion, may reflect increased distal reabsorption with early volume expansion [5].

Stop-flow studies in dogs have shown that lactate is actively reabsorbed in the proximal tubule [11]. Other studies have demonstrated that lactate excretion is dependent upon the rate of flow of urine and increases beyond quantities which can be explained by urine flow when extracellular fluid is expanded by infusion of isotonic saline [11]. The data obtained during bicarbonate titration in our patient demonstrate that in the human also lactate excretion is related to the degree of volume expansion.

Lactate uptake by the kidney is related to sodium transport [10], a decrease in lactate uptake occurring with increases in fractional sodium excretion. Primary modification of net sodium transport may be reflected by changes in renal lactate uptake; but the absence of elevated levels of lactate in chronic renal disease [6] where marked depression of proximal reabsorption of sodium has been demonstrated indicates that it is not a defect in sodium reabsorption which causes the elevated lactate levels in our patients. Yet, as speculated by Dies et al. [12] the inability of lactic acid to be adequately metabolized in idiopathic lactic acidosis, may represent the ultimate failure of adequate energy for and/or of the appropriate carrier substance for sodium transport. In such a case, a sodium leak might lead to failure of bicarbonate reabsorption.

Blood lactate levels rise with both metabolic and respiratory alkalosis in both animals and man [28]. The increase in lactate level rarely exceeds 2 to $3 \mathrm{~mm} /$ liter in man and is usually not progressive with persistence of the alkalosis. The lactate level for our subject rose progressively as the serum bicarbonate level rose. In another child in whom bicarbonate infusion raised serum $\mathrm{HCO}_{3}-$ levels to similar values, venous lactate levels rose only to levels one-half as high as those in our patient with SNE [20]. A precise explanation for the increase in lactate levels in alkalosis cannot be given. It is of interest, however, that when sodium lactate was given intravenously to two children with lactic acidosis [23], the blood lactate levels rose to higher levels than in a control subject and remained at high levels longer. It may be that in such children, decreased utilization of lactate will explain the progressive increase in serum lactate levels as serum bicarbonate levels increase. On the other hand, lactate production by the erythrocyte has been shown to be increased in one child with SNE [2I] and normal in another [23].

Lactic acidosis results from either an increase in pyruvate or a change in the ratio of $\mathrm{NADH}$ to $\mathrm{NAD}^{+}$. When tissue hypoxia occurs, accumulation of "excessive lactate" leads to a change in the lactate/pyruvate $(\mathrm{L} / \mathrm{P})$ ratio. There was no evidence for hypoxia in our patient. We did not measure pyruvate, but others have found the $\mathrm{L} / \mathrm{P}$ ratio in SNE to be normal. Such observations suggest that the lactic acidosis seen in $\mathrm{SNE}$ reflects an increased pyruvate level and that lactic dehydrogenase activity is normal.

Several investigators have observed elevated levels of plasma alanine and blood lactate in patients with SNE $[29,39]$. Increased levels of these substances in blood suggested a reduction in the utilization of pyruvate, the possibility of increased formation of pyruvate from glucose having been excluded. In the mitochondria, pyruvate is metabolized to acetyl coenzyme-A and to oxaloacetate by pyruvate dehydrogenase complex (EC. 1.2.4.1) and by pyruvate carboxylase, respectively. Hommes et al. [22] and Tada et al. [35] found negligible amounts of pyruvate carboxylase in a liver biopsy specimen obtained from two patients suffering from SNE and suggested that this disorder may be an inborn error of deriving glucose from noncarbohydrate precursors via gluconeogenic pathways. Pyruvate and lactate can serve as precursors for glucose synthesis, lactate produced in peripheral tissues via glycolysis being converted into glucose by either liver or kidney. The first step in the conversion of pyruvate into glucose involves mitochondrial pyruvate carboxylase. If there were decreases in the activity of pyruvate carboxylase in the liver and kidney in SNE, then diminished conversion of pyruvate to glucose would explain the elevated levels of blood pyruvate, lactate, and plasma alanine.

The level of pyruvate carboxylase activity in the liver of $M G$ was investigated. Grover et al. [19] found considerable activity of pyruvate carboxylase in a liver bropsy at 10 months of age, but negligible enzyme activity was found in the liver at autopsy. The low Ievel of hepatic pyruvate carboxylase may not have been an etiologic factor, but only secondary to the disease process.

The very low level of pyruvate carboxylase in the 
kidney may represent either a congenital defect or the result of the disease process. The latter is more likely in our patient, since hepatic pyruvate carboxylase activity was within the normal range earlier in the course of the disease, when RTA was found.

Because ATP is generated in the renal cortex by metabolism of pyruvate, a reduction in pyruvate metabolism may decrease the generation of energy in the renal cortex. The diminished supply of energy might then account for inadequate reabsorption of filtered bicarbonate. Because the excretion of ammonium in response to acidosis was within expected limits, it may be suggested that the metabolism of glutamate was not affected.

\section{Summary}

Proximal RTA has been found in two children with SNE. The data warrant the inclusion of RTA as part of the clinical spectrum of Leigh's syndrome. In addition, changes in the renal excretion of urate, chloride, phosphate, and lactate have been shown to be associated with expansion of ECF volume when infusing bicarbonate. Reduced renal pyruvate carboxylase activity was found postmortem in one child.

\section{References and Notes}

1. Ballard, F. J., and Hanson, R. W.: The citrate cleavage pathway and lipogenesis in rat adipose tissue: Replenishment of oxaloacetate. J. Lipid Res., 8: 73 (1967).

2. Bat.rard, F. J., HANSON, R. W., ANd REshef, L.: Immunochemical studics with soluble and mitochondrial pyruvate carboxylase activities from rat tissues. Biochem. J., 119: $735(1970)$.

3. Barker, S. B., AND Summerson, W. H.: The colorimetric determination of lactic acid in biological material. J. Biol. Chem., 138: 335 (1941).

4. Bonsnes, R. W., and Taussky, H. H.: On the colorimetric determination of creatinine by the Jaffe reaction. J. Biol. Chem., 158: 581 (1945).

5. Buckalfew, V. M., JR., Whlker, B. R., Puschett, J. B., and GoldberG, M.: Effects of increased sodium delivery on distal tubular sodium reabsorption with and without volume expansion in man. J. Clin. Invest., 49: 2336 (1970).

6. Caldis, L., Castelito, F., Fortuny, G., Vatio, A., and BallaBRIGA, A.: Effect of hyclrochlorothiazicle on rickets and on renal tubular acidosis in two patients with cystinosis. Helv. Pacdiat. Acta., 6: 602 (1970).

7. Caraway, W. T:: Determination of uric acid in serum by a carbonate method. Amcr. J. Clin. Pathol., 25: 840 (1955).

8. Clayton, B. E., Dobis, R. H., and Patrick, A. D.: Leigh's subacute necrotizing encephalopathy: Clinical and biochemical study, with special reference to therapy with lipoate. Arch. Dis. Child., 42: 467 (1967).

9. Cotlove, E., Trantham, H. V., and Bowman, R. L.: An instrument and method for automatic rapid, accurate and sensitive titration of chloride in biologic samples. J. Lab. Clin. Med., 51: 461 (1958).

10. Dies, F., Herrera, J., Matos, M., Avelar, E., and Ramos, G.: Substrate uptake by the dog kidney in vivo. Amer. J. Physiol., 218: 405 (1970).

11. Dies, F., Ramos, G., Avelar, E., and Lennhoff, M.: Renal excretion of lactic acid in the dog. Amer. J. Physiol., 216: 106 (1969).

12. Dies, F., Ramos, G., Avelar, E., And Matos, M.: Relationship between renal substrate uptake and tubular sodium reabsorption in the dog. Amer. J. Physiol., 218: 411 (1970).

13. Edelmann, C. M., Jr., Barnett, H. L., Stark, H., Borchis, H., AND Soriano, J. R.: A standardized test of renal concentrating capacity in children. Amer. J. Dis. Child., 114: 659 (1967).

14. Edermann, C. M., JR., Soriano, J. R., Boichis, H., Gruskin, A. B., ANd Acosta, M. I.: Renal bicarbonate and hydrogen ion excretion in normal infants. J. Clin. Invest., 46: 1300 (1967).

15. Erickson, R. J.: Familial infantile lactic acidosis. J. Pediat., 66: $1004(1965)$.

16. Galloway, R. E., and Morgan, J. M.: Serum pyruvate and lactate in uremia. Metabolism, 13:818 (1964).

17. GAMble, J. L., JR.: The chloride space, arithmetic and deficit therapy. Pediatrics, 30: 990 (1962).

18. Gomori, G.: A modification of the colorimetric phosphorus determination for use with the photoelectric colorimeter. J. Lab. Clin. Med., 27: 955 (1941).

19. Grover, W. D., Auerbach, V. H., and Patel, M. S.: Biochemical studies and therapy in subacute necrotizing encephalomyelopathy (Leigh's syndrome) J. Pediat., 81: 39 (1972).

20. Gruskin, A. B.: Unpublished observations.

21. Hartmanin, A. F., Sr., Wohltmann, H. J., Purkerson, M. L., AND Wrsley, M. E.: Lactate metabolism. J. Pediat., 61: 165 (1962).

22. Hommes, F. A., Polman, H. A., and Reerink, J. D.: Leigh's encephalomyelopathy: An inborn error of gluconcogenesis. Arch. Dis. Childhood, 43: 423 (1968).

23. Israels, S., Haworth, J. C., Gourley, B., and Ford, J. D.: Chronic acidosis duc to an error in lactate and pyruvate metabolism. Pediatrics, 34: 346 (1964).

24. Jorgensen, K.: Titrimetric determination of the net excretion of acid-base in urine. Scand. J. Clin. Lab. Invest., 9: $287(1957)$.

25. Keisch, R. C., AND Oliver, W. J.: Studies on dictary correction of metabolic abnormalities in hepatorenal glycogenosis. Pediat. Res., 3: 160 (1969).

26. LeIGH, D.: Subacute necrotizing encephalomyclopathy in an infant. J. Neurol. Neurosurg. Psychiat., 14: 216 (1951).

27. OETlikfr, O., AND Rossi, E.: The influence of extraccllular fluid volume on the renal bicarbonate threshold. A study of two children with Lowe's syndrome. Pediat. Res., 3: 140 (1969).

28. Or.rva, P. B.: Lactic acidosis. Amer. J. Med., 48: 209 (1970).

29. Robinson, F., Solitare, G. B., Lamarche, J. B., ANd Levy, L. L.: Necrotizing encephalomyelopathy of childhood. Ncurology, 17: 472 (1967).

30. Robson, A. M., Srivastava, P. L., and Bricker, N. S.: The influence of saline loading on renal glucose reabsorption in the rat. J. Clin. Invest., t7: 329 (1969). 
31. Smith, H. W., Finkelstein, N., Aliminosa, L., Crawford, B., AND Grader, M.: The renal clearances of substituted hippuric acid derivatives and other aromatic acids in dog and man. J. Clin. Invest., 23: 388 (1945).

32. Sortano, J. R., Boichis, H., and Edelmann, C. M., Jr.: Bicarbonate reabsorption and hydrogen ion excretion in children with renal tubular acidosis. J. Pediat., 71: 802 (1967).

33. Soriano, J. R., and Edelmann, C. M., Jr.: Renal tubular acidosis. Annu. Rev. Med., 20: 363 (1969).

34. Swan, R. C., Axelros, D. R., Seip, M., and Pitts, R. F.: Distribution of sodium bicarbonate infused into nephrectomized dogs. J. Clin. Invest., 34: 1795 (1955).

35. TAda, K., Yoshida, T., Konno, T., Wada, Y., Yokoyama, Y., AND ARAKaw, T.: Hyperalaninemia with pyruvicemia. Tohoku J. Exp. Med., 97: 99 (1969).

36. UTrer, M. F., AND KeEch, D. B.: Pyruvate carboxylase. I. Nature of reaction. J. Biol. Chem. 238: 2603 (1963).

37. VAN Slyke, D. D., AND WEILI, J. M.: The determination of gases in blood and othex solutions by vacuum extraction and manometric measurement. J. Biol. Chem., 61: 523 (I924).

38. Walser, M., Davidoson, D. G., ANd Orlofe, J.: The renal clearance of alkali-stable inulin. J. Clin. Invest., $3+2: 1520$ (1955).

39. Worstex, H. E., Brookfield, R. W., Elwood, J. S., Noble, R.
L., AND TAYlor, W. H.: Lactic acidosis with necrotizing encephalopathy in two sibs. Arch. Dis. Childhood, to: 492 (1965).

40. Instrumentation Laboratory, Watertown, Mass.

41. Corning Glass Works, Corning, N. Y.

42. Fisher Scientific Company, Pittsburgh, Penn.

43. Phoenix Precision Instruments, Philadelphia, Penn.

44. Advanced Instruments, Inc, Newton Highiands, Mass.

45. Except as specifically stated, all data pertain to our male subject, $M G$.

46. The authors wish to thank Mrs. M. Comroc for her valuable technical assistance and V. C. Vaughan III for reviewing the manuscript.

47. Presented in part at the Second Intcrnational Congress of Pediatric Nephrology, Paris, August, 1971.

48. Dr. Linshaw was a Postdoctoral Research Fellow of the Public Health Scrvice under Training Grant no. T1-HD-66.

49. This research was supported in part from grants from the National Institutes of Health, Clinical Rescarch Center (RR-75), General Research Support (RR-5624), Research Grants NS-10125, HD-05874 and HE-12651.

50. Requests for reprints should be addressed to: AlaN B. Gruskin, M.D., Director of Pediatric Nephrology, St. Christopher's Hospital for Children, 2600 N. Lawrence St., Philadelphia, Penn. 19113 (USA).

51. Accepted for publication Junc 7, 1973. 